\title{
BEBERAPA ASPEK NEGARA DAN HUKUM DALAM SISTEM ADAT BUGIS Jumadi
}

\author{
Universitas Islam Negeri (UIN) Alauddin Makassar
}

Email: Jumadirahman263@yahoo.com

\begin{abstract}
The state or bocco was born on a partnership between the First King and the people, solely to continue the noble ideals of the people. The ideal arises in the feeling of the law for the sake of order and prosperity. The people in the agreement were not considered as objects of arrangement in it contained in the rights of the authorities and the people, then placed the miracle obligations that they held. The purpose of the king's policy is in accordance with the will of the law and the rights needed by the community. Similarly, the state administration is displayed by the ability to rule Mata Silompoe. The king formed a government structure in accordance with the conditions and needs, where in the beginning there were seven small (royal) communities that supported him. The common goal is realized by uniting oneself in government. Viewed from the point of view of the modern constitutional system that was formed and carried out by the results of the To Manurung agreement, it did not miss much of the values of modern power today.
\end{abstract}

Keywords: Country, Bugis Adat

\begin{abstract}
Abstrak
Negara atau bocco lahir atas perjanajian antara Raja Pertama dengan rakyat, semata-mata untuk meneruskan cita-cita luhur rakyat. Cita-cita itu muncul dalam perasaan hukum demi ketertiban dan kesejahteraan. Rakyat dalam perjanjian itu tidak dianggap sebagai objek pengaturan di dalamnya tertuang hak penguasa dan rakyat, kemudian diletakkan kewajiban-kewajaiban yang dipangkunya. Tujuan kebijakan raja sesuai dengan kehendak hukum dan hak-hak yang dibutuhkan oleh masyarakat.Demikian pula ketatanegaraan ditampilkan oleh kemampuan memerintah Mata Silompoe. Raja membentuk truktur pemerintahan sesuai dengan kondisi dan kebutuhan, dimana pada awalnya terdapat tujuh komunitas (kerajaan) kecil yang mendukungnya. Tujuan bersama diwujudkan dengan mempersatukan diri dalam pemerintahan. Dilihat dari sudut sistem ketatanegaraan modern yang dibentuk dan dijalankan oleh hasil perjanjian To Manurung tidak banyak meleset dari nilai-nilai kekuasaan modern dewasa ini.
\end{abstract}

Kata Kunci: Negara, Adat Bugis 


\section{PENDAHULUAN}

B ahasa menunjukkan bangsa. Ini adalah pepatah klasik. Namun sesungguhnya suku bangsa Bugis itu tergolong salah satu bangsa, baik pada masa pra-Hindia Belanda maupun saat ini. Apalagi suku bangsa ini diperkuat dengan aksara yang khas dan unik yaitu aksara lontarak.

Jelasnya, bahwa di kepulauan ini terdapat beberapa suku bangsa yang memiliki aksara khas antara lain, Jawa, bali, Batak dan Bugis. Tanpa aksara tidaklah mungkin mengungkapkan, memahami dan menggali suatu budaya dan hasil-hasilnya. Justru kebudayaan itu termuat dalam inskripsi/epigraf yang tertullis dalam aksara bangsa itu. Mesir, India dan Tiongkok dengan aksaranya maka para arckeoog, antropolog atau etnolognya mampu mengkaji lebih dalam kebudayaannya. Demikian pula dengan kebudayaan Bugis dengan aksara lontaraknya mampu menampilkan budaya dan hasil-hasilnya.

Kebudayaan adalah keseluruhan sistem gagasan, tindakan dan perbuatan dan hasil karya manusia dalam rangka kehidupan masyarakat yang dihasilkan dengan proses belajar. Ralph Linton mengemukakan bahwa kebudayaan itu adalah konfigursi tingkah laku yang dipelajari dan hasil tingkah laku yang unsur-unsur pembinanya dimiliki bersama dan dilanjutkan oleh anggota masyarakat tertentu. Kebudayaan juga merupakan keseluruhan kompleks yang meliputi ilmu, kepercayaan, kesenian, tata susila, hukum adat-istiadat dan kesanggupan-kesanggupan yang lain dipelajari dari anggota-anggota masyarakat. ${ }^{1}$

Ada tiga wujud kebudayaan, yaitu sistem budaya, sistem sosial dan hasil nyata budaya yang satu sama lain berhubungan secara timbal balik dan saling berhubungan dengan struktur kebudayaan. Struktur kebudayaan yang dimaksud antara lain adalah sistem politik yang mengatur hubungan antara anggota masyarakat terutama yang barkaitan dengan pembagian tugas dan penyelenggaraan kekuasaan. Kekuasaan kerajaan yang dianut oleh bangsa Bugis zaman dulu adalah berbentuk monarchi atau kerajaan.

Menanggapi sistem pemerintahan yang telah berlangsung pada zaman dahulu itu ternyata berbeda-beda. Bagi generasi muda yang berwawasan terkini sering mengemukakan bahwa kebudayaan masa lalu, khususnya bentuk pemerintahan monarchi, tidak lain hanya sebagai benteng-benteng yang tidak menghasilkan faedah untuk masyarakat. Sistem birokrasi, pemerintahan dan hukum diharapkan lebih bersifat nasional modern, bukan regional archais seperti yang terjadi pada masa lampau. Dengan demikian tidaklah jelek apabila pada waktu-waktu tertentu dicoba untuk diberi penilaian tentang sampai dimanakah

\footnotetext{
${ }^{1}$ Koentjaraninrat, Manusia dan kebudayaan Indonesia, Djambatan, Jakarta, 1976. Lihat pula Metode-Metode Antropologi (Disertasi) 1958 hal. 193
} 
pembinaan persatuan nasional dengan usaha-usaha kebudayaan atau sampai dimanakah arah perkembangan kebudayaan-kebudayaan daerah memperkuat persatuan itu, apakah tidak terjadi sebaliknya. Sampai dimana diperoleh kemajuan di bidang modernisasi yang sungguh-sungguh merupakan perolehan yang relevan, yang juga membantu menempatkan warga sebagai bangsa dalam suatu negara yang kuat dan memiliki unsur kebebasan yang dapat diterapkan pada abad ke dua puluh satu?

Kebudayaan nasional yang baru saja tumbuh ini, harus pula dikaitkan dengan kebudayaan lain di kepulauan nusantara ini, setidak-tidaknya terhadap puncak-puncak kebudayaan daerah tertentu yang mempunyai usia lebih tua (berkuasa lebih lama). Dapatlah dikatakan bahwa kebudayaan nasional bangsa Indonesia adalah kelanjutan dari kebudayaan daerah. Berarti puncak kebudayaan daerah adalah kebudayaan nasional yang modern, tanpa meninggalkan atau tetap mempertahankan unsur-unsur kebudayaan tradsional yang baik dan berwawasan modern. Kebudayaan daerah yang dimaksud akan menjadi ciri, melekat sebagai identitas nasional Indonesia.

Salah satu kebuayaan daerah di Sulawsi Selatan yang terkenal adalah Bugis. Penekanan ini mengingatkan terdapatnya eks sejumlah kerajaan yang mendiami wilayah hukum tertentu yang cenderung memiliki dialeg sama. Misalnya dialeg Bone, Soppeng, Wajo, Sidenreng, Sinjai, Maros, Bulukkumba, Maros Barru, Pinrang dan lain-lain.

Kesemua wilayah hukum berdialeg Bugis diatas terdapat pula eks kerajaan besar lain yang memiliki ciri khas kebudayaannya, bahkan dapat diklasifikasikan sebagai kerajaan imperium yang pernah memegang hegemoni. Kerajaan yang dimaksud adalah Tellumpoccoe, yakni Bone, Luwu dan Gowa. Kerajaankerajaan yang dimaksud sering menaklukkan kerajaan lain yang lebih kecil lainnya.

Tampaknya, bocco (kerajaan besar) inilah yang menjadi prototype imperium yang pada gilirannya mengakibatkan terjadinya perebutan hegemoni. Bone, Luwu dan Gowa adalah kerajaan setara, namun dalam proses pertumbuhannya terdapat beberapa perbedaan sistem birokrasi dan pemerintahan. Sistem yang dipakai itu, meskipun tidak cocok lagi dengan kondisi sekarang, namun tidak begitu saja dibuang, karena tidak ada salahnya apabila masa lampau itu dipelajari, dikaji terutama pada puncak-puncak kebudayaan daerah yang membawa tingkat kejayaan, kebesaran dan keagungannya. Sistem birokrasi dan pemerintahan tiga boco ini adalah kebudayan daerah yang bhinneka di kepulauan (nusantara) dan perlu dilestarikan. Maksudnya sebagai penunjang tegak 
tumbuhnya kebudayaan nasional atau sebagai akar kuat tertanam mendukung dan mempertahankan negara kesatuan Republik Indonesia.

Kerajaan besar Bugis tumbuh dan berkembang sebagaimana sistem adat yang dijalankan. Namun perlu dikaji lebih dalam bahwa dalam ilmu Negara terdapat teori tentang lahirnya suatu Negara dan terdapat pembagian kekuasaan berdasarkan ajaran trias politica. Apakah bocco lahir dengan menggunakan ukuran - ukuran ilmu ketatanegaraan modern? adakah aspek hukum yang menyertai penegakan sistem, adat kerajaan dan bagaimana bentuknya?

\section{PEMBAHASAN}

\section{Hukum Ketatanegaraan Adat}

Berdasarkan waktu pembabakan sejarah Indonesia, berbagai bentuk dan sistem pemerintahan negara-negara, ternyata terdapat negara yang masih mempertahankan sistem dan eksistensinya hinggga tahun 1970-an. Organisasi tersebut menurut Van Vollen Hoven, masih pantas untuk disebut negara.

Pernyataan itu menunjukkan keanekaragaman lembaga yang disebutnya sebagai tatanan rakyat atau tatanan kekuasaan. Keanekaragaman ini tidak terlepas dari lingkaran hukum adat yang telah diakannya terhadap wilayah dan sistem hukum adat di Indonesia.

Hukum mengenai lembaga yang dimaksud adalah hukum tatanegara adat, salah satu lapangan hukum dan sistem hukum adat. Menurut ahli hukum adat, hukum tatanegara adat sangat ditentukan oleh tatanan masyarakat, yang lazim disebut persekutuan hukum atau masyarakat hukum. Untuk dapat dikualifikasikan sebagai persekutuan hukum diperlukan syarat gerdende groepen van blijvend karakter met iegen bewind en eigen materiel en immaterieel vermogen. ${ }^{2}$

Persekutuan hukum yang syarat-syaratnya telah diajukan itu, bentuknya dapat dibedakan berdasarkan faktor-faktor yang mempengaruhinya yakni faktor geneologi atu territorial. Inilah kemudian menciptakan persekutuan hukum geneologis atau pun persekutuan hukum territorial atau gabungan dari keduanya.

Kalaupun volksordering dan gezagsordering dipandang sebagai negara, maka tidak lain merupakan suatu bentuk persekutuan hukum, Namun tidak semua persekutuan hukum diklasifikasikan sebagai negara, karena terdapatnya persekutuan hukum yang merupakan bagian dari persekutuan hukum lebih besar,

${ }^{2}$ Ter Haar, Azas-Azas Hukum Adat ( Terjemahan dari judul : Beginselen en Stelsel Van Het Adat Recht ) Djambatan, Jakarta, 1939, h. 14. 
bahkan ada yang menjadi unsur persekutuan hukum yang besar atau persekutuan dari sejumlah persekutuan hukum. ${ }^{3}$

Bentuk persekutuan hukum yang dipengaruhi oleh faktor territorial menurut Ter Haar dapat dibedakan ke dalam bentuk persekutuan desa dan persekutuan wilayah dari desa. ${ }^{4}$ Dapat pula disebut dengan istilah masyarakat hukum tunggal, bertingkat dan masyarakat hukum berangkai. ${ }^{5}$ Ter Haar kemudian mempertentangkan persekutuan hukum itu dengan lingkungan raja-raja, walaupun diakuinya bahwa ada pertalian yang erat. Hal ini dapat difahami, dalam kurung waktu Penjajahan Hindia Belanda sampai pada tahun 1910 masih terdapat beberapa kerajaan yang ingin mempertahankan bentuk aslinya meskipun telah berubah status setelah tahun 1910. Antara kerajaan dan persekutuan hukum dalam berbagai bentuk itu, tidak hanya memiliki pertalian erat, melainkan tidak dapat dipisahkan satu dengan lainnya. Kerajaan adalah salah satu bentuk persekutuan hukum dan persekutuan hukum adalah suatu bentuk negara, bagian dari padanya atau unsurnya menjadi serikat suatu negara. Persekutuan hukum itulah yang disebut negara atau kerajaan (setelah tahun 1910 secara berangsur-angsur dikuasai langsung atau tidak langsung oleh lingkungan kekuasaan Hindia Belanda).

Persekutuan hukum seperti itu yang dijadikan objek pembahasan adatstaatrechts $^{6}$ oleh Van Vollen Hoven. Diakui oleh Ter Haar dengan mengadakan rincian lebih lanjut mengenai vermogen yang bersifat materiel dan immaterieel, bahkan menggantikan istilah lichaam dan gezag dari Van Vollen Hoven dengan gerdende groepen met blijvend karakter serta bewind. Akan tetapi pembahasan Ter Haar mengenai volksordening atau pembahasan Soepomo tentang tata susunan rakyat Indonesia sama sekali tidak menggunakan istilah adatstaatrecht (hukum tatanegara adat).

Logeman yang menulis tetang Hukum Tatanegara Hindia Belanda mengakui status hukum tata negara adat. Menurutnya terjadi sifat dualilstis atas hukum tatanegara Hindia Belanda karena dua aunsur yang berbeda dalam strukturnya. Kedua unsur itu adalah hukum tatanegara adat yang strukturnya bersumber dari organisasi masyarakat Indonesia, yang lain adalah hukum

\footnotetext{
${ }^{3}$ Hal ini dapat dibanadingakan dengan negara terhadap daerah kekuasaan yang tingkatannya lebih rendah dari negara-negara berserikat (federasi atau konfederasi) menurut hukum tata negara modern.

4 Ter Haar, Ibid. hal. 19.

${ }^{5}$ Soleman B, Toneko, 1983. H.111

${ }^{6}$ Istilah Adatstaatrecht ini pertama kali diperkenalkan oleh Van Vollen Hoven, kemudian Van Dijk menggunakan istilah lain yaitu Hukum Adat Tatanegara yang makna dan ruang lingkup pembahasannya meliputi hukum tata negara adat.
} 
tatanegara Hindia Belanda dimana strukturnya bersumber dari masyarakat Belanda yang bersuasana masyarakt Barat. Gaya seperti itulah kemudian dibentuk menjadi hukum tatanegara versi Belanda dengan menyerap berbagai lembaga hukum tradisional Indoneia.

Bahasan adatstaatrecht dari Van Vollen Hoven meliputi masyarakat persekutuan hukum di Indonesia, ${ }^{7}$ dalam arti sempit atau tidak termasuk hukum administrasi negara. Kemudian menguraikan tentang dasar-dasar berlakunya, kedudukannya, kesubjekan rechtsgemenschappen, fungsi-fungsi bestuur, polite, regeling, domeinverklaring, rechtspraak dan sebagainya. Selain itu dibahas pula secara khusus, adatstaatrecht van uitnemsche oosteningen dan intergentiel staatsrecht. Hal ini menunjukkan adanya fluralisme hukum ketika itu, termasuk hukum tatanegaranya. Jadi istilah apapun yang digunakan dalam pembahasan mengenai persekutuan hukum atau masyarakat hukum, dilihat sebagai satu bentuk negara atau bagian suatu negara menurut sistem hukum pada kurun waktu tertentu.

Negara sebagai istilah modern yang dikenal dalam hukum tatanegara berasal dari Barat (Eropa Barat pada apab XIV), meskipun di Indonesia telah dikenal sejak zaman purba. ${ }^{8}$ Di Jawa dikenal dengan istilah negara yang diartikan sebagai kerajaan, keraton yang juga berarti rakyat. Menurut Mustamin Daeng Matutu, ${ }^{9}$ istilah negara (modern) muncul di Eropa barat pada zaman reneissance (abad XV) dengan istilah Lo stato (Italia) kemudian menurunkan kata seperti I'etat (Prancis), the state (Inggeris), de Staat (Jerman). Lo stato sendiri diartikan sebagai sistem tugas-tugas atau fungsi-fungsi publik dan alat-alat perlengkapan yang teratur, membentang luas di atas suatu wilayah tertentu.

Sebenarnya negara itu tidak lain merupakan organissasi sosial yaitu organisasi kemasyarakatan yang diberi kekuasaan (wewenang) tertinggi tanpa perlu mempersoalkan berdaulat tidaknya organisasi itu. Soal kedaulatan hanyalah salah satu unsur negara yang harus dipenuhi untuk mendapat status pengakuan sebagai subjek hukum internasional. Kedaulatan itu ditempatkan bahwa negara itu tidak berada dibawah kekuasaan asing. ${ }^{10}$ Unsur negara meliputi, kekuasaan

\footnotetext{
${ }^{7}$ Mohamammad Koeno, Hukum Mengenai Tata Susunan Masyarakat Dalam Hukum Adat, 1972 , h.2

${ }^{8}$ Utrecht - M. Saleh Djindang, Pengantar Dalam Hukum Indonesia, Jakarta, Sinar Harapan Balai Buku Ikhtiar, 1983, h.360.

9 Mustaming Dg. Matutu (Dosen Fakultas Hukum Unhas) Selayang Pandang (tentang) Perkembangan Tipe-tipe Negara-Negara Modern, Pidato Lustrum IV, Fakultas Hukum Unhas, Ujung Pandang, 1972.

${ }^{10}$ Ibid h. 360.
} 
tertinggi, wilayah (lingkungan kuasa) dan warga negara atau bangsa negara (rakyat). ${ }^{11}$ Kedaulatan bukanlah unsur mutlak atau ciri. ${ }^{12}$

Negara memperoleh kekuasaan didasarkan pada salah satu teori yang social contract (perjanjian masyarakat). Teori ini masuk dalam golong teori hukum alam (natural law). Ciri essensial teori ini berpangkal tolak dari keadaan alamiah tanpa hukum, tanpa tata tertib dan pemerintahan. Suasana seperti itu ada yang menggambarkannya sebagai chaos. Suatu ketika masyarakat melakukan perjanjian untuk menciptakan kondisi damai dan saling menghormati, maka perjanjian ini disebut pactum unions (kesepakatan bersama). Perjanjian ini disusul kemudian dengan kesepakatan untuk bersatu dan menaati pemerintah yang telah dipilih oleh mereka secara bersama (pactum subectionis). Tahap awal perjanjian ini dipandang sebagai kejadian sesungguhnya sebagai peristiwa. Grotius melihat sebagai fakta sejarah. Sedangkan yang terjadi berikutnya bukan lagi peristiwa sejarah, tetapi oleh Kant melihatnya sebagai sustu konstruksi penalaran hukum. ${ }^{13}$

Pendukung teori perjanjian masyarakat ini memiliki persamaanpersamaan, khususnya penemuan mereka atas sumber kekuasaan politik dari rakyat dan menentang deduksi kekuasaan politik yang berasal dari hukum abadi (devine law). Semua penganut teori ini menjadi pelopor teori demokrasi. ${ }^{14}$

Aspek hukum lainnya dari teori ini tertuju pada konsepsi masyarakat yang individualistis. Negara dipandangnya sebagai suatu kreasi hukum dan berasal dari kehendak individu. Perjanjian ini menjadi bentuk ideal untuk konsepsi masyarakat demikian, meskipun menurut Friedman bahwa konstruksi perjanjian masyarakat sangat sedikit kaitannya dengan aturan-aturan hukum modern dan perjanjian perdata.

Grotius menggunakan konstruksi perjanjian masyarakat untuk tujuan ganda, pertama ke dalam sebagai pembenaran terhadap kewajiban absolut rakyat taat kepada pemerintah. Kedua ke luar untuk menciptakan dasar ikatan hukum dan hubungan yang stabil antar negara-negara (hubungan internasional).

Perjanjian masyarakat adalah fakta sejarah umat manusia. Konstruksi suatu negara senantiasa didahului dengan perjanjian masyarakat, dalam arti bahwa orang perseorangan di dalam masyarakat memilih sistem pemerintahan yang cocok baginya, tetapi Grotius mengingatkan bahwa pemerintah diadakan untuk

\footnotetext{
${ }^{11}$ Ibid, h.381.

${ }^{12}$ Logeman, Over de Theorie Van een Steling Staatrecht. NV. Mahabarata, Amsterdam, 1947, h.5

${ }^{13}$ Dalam Friedman, Legal Theori, Steven and Sons Ltd. 1953, h. 40.

14 Ibid.
} 
kepentingan yang diperintah. Ia hanya terikat pada hukum alam, sekalipun tanpa melakukan perjanjian. Ketertiban dan stabilitas internasional itulah yang paling diutamakan.

Teori perjanjian masyarakat dilakukan bertujuan untuk: pertama, menentang konsepsi abad pertengahan yang dibentuk oleh rakyat yang berbeda. Kedua untuk memberikan kebebasan kepada pemerintah (penguasa) yang mengadakan hubungan luar negeri dari setiap pembatasan atau belenggu intern. Ketiga penekanan terhadap kekuatan mutlak dari suatu janji yang diucapkan.

Tujuan ketiga yang dikemukakan di atas bertentangan dengan pengingkaran terhadap maksud diadakannya suatu pemerintahan yang antara lain adalah untuk kepentingan yang diperintah. Kontradiksi menunjukkan adanya ketidak konsistenan pandapat Grotius terhadap perjanjian masyarakat tadi. Meskipun harus diakui bahwa Grotius menulis buku dilatarbelakangi oleh kepentingan politik. ${ }^{15}$

Hobbes mengakui otoritas hukum alam, akan tetapi pemahamannya berbeda secara mendalam dengan mereka yang menganggap hukum alam lebih tinggi kedudukannya dengan hukum positif. Ia menggeser penekanannya mengenai hukum alam sebagai tatanan objektif menjadi hak-hak alami (natural rights). Hak alami sebagai tuntunan objektif berdasarkan hakekat manusia. Pandangan Hobbes dapat merestui kesempatan munculnya suatu revolusi individualisme dengan alas an bahwa hak-hak alami tidak dapat dipindahtangankan. Hobbes sesungguhnya masih mengakui aturan objektif dari hukum alam yang bersifat tetap, akan tetapi meninggalkan sanksi-sanksinya. Baginya hukum alam tidak lagi bersifat aturan etika tertentu, melainkan aturan untuk bertindak bagi umat manusia dengan menyandarkan observasi dari apresiasi hakikat manusia. Azas utama yang diajukan adalah perlindungan atas diri sendiri, berkaitan dengan pandangannya tentang suasana alami manusia hidup kacau balau tanpa penguasa, saling berperang, manusia mengejar keuntungan sendiri-sendiri tanpa menghormati yang lainnya, dan menikmati hak-haknya tanpa batas. Suasana yang demikian kejam ini menimbulkan berbagai macam ancaman dari pembinasaan setiap orang. Namun karena adanya self preservation, mereka mencari jalan ke luar dari ketidakpastian kehidupan semacam itu. Warga kemudian menyerahkan hak-hak alaminya kepada penguasa seraya berjanji untuk menaatinya tanpa syarat.

\footnotetext{
${ }^{15}$ Selain Grotius yang menulis buku untuk tujuan politk, juga John Loke dan Thomas Hobbes seperti dalam buku De Cive (1642) dan Leviathan (1651) Dalam Friedman, Ibid, h. 41-45.
} 
Hobbes tidak mengenal macam-macam perjanjian dalam masyarakat . Menurutnya hanya satu yaitu factum subjectionis tanpa syarat, yaitu seluruh hak alami dari rakyat diserahkan kepada penguasa, sehingga memperoleh kekuatan absolut. Hobbes menolak setiap bentuk perjanjian yang memperjanjikan hak (kuasi perjanjian), yang memberi peluang kepada masyarakat untuk melaksanakan kewajiban penguasa Perjanjian tersebut sesungguhnya bukanlah perjanjian yang sebenarnya, atau hanya sebagai perjanjian fiksi logika (logical fiction) belaka. Kekuasaan absolut diikuti dengan syarat bahwa berhak memerintah dan menjaga ketertiban. Konsepsi kedaulatan yang berasal dari perjanjian di sini sepenuhnya rasional, utilitarian dan cenderung bersifat monarchi.

John Locke penentang utama aliran Hobbes, yang juga termasuk penganut teori perjanjian masyarakat melihatnya berbeda. Teori yang diajukan tidak mendemostrasikan seluruh hak-hak alami kepada penguasa, bahkan sebaliknya, mempersempit gerakan hak alami untuk membenarkan suatu pemerintahan mayoritas. Juga menampilkan anggapan bahwa penguasa dibentuk untuk mengangkat kepercayaan disertai dengan kewajiban untuk melindungi hak-hak individu. John Locke mendemostrasikan beberapa gagasan pada abad pertengahan, khususnya yang berasal dari Hooker tentang penguasa dan kekuatan mengikat dan azas-azas moral tertentu terhadap pemerintah, dengan menerima banyak premis individualistis Hobbes. Nilai itu kemudian dideklarasikannya sebagai natural rights. Menurut Locke individu mempunyai hak-hak alami bawaan yang antara lain disebut liberty atau estate. Keadaan alamiah menurutnya adalah surga yang hilang. Suatu keadan damai, saling bantu dan saling melindungi serta suatu keadaan yang demikian harmonis juga termasuk keadaan alamiah. Dalam keadaan seperti itulah sehingga alam memberikan hak padanya, meskipun belum mempunyai organisasi. Sumbangan esensi dari Locke ini yakni menjabarkan hak-hak azasi manusia, selain itu memberi kemungkinan terlindunginya, terpeliharanya hak-hak alamiah manusia. ${ }^{16}$

Teori perjanjian masyarakat digunakan dalam fungsi ganda. Pertama, dengan pactum unionis tdalam sebuah political sociaty sebagai kebutuhan individu yang menjadi anggota masyarakat dalam pemerintahan sipil persemakmuran. Kesepakatan mayoritas itu identik dengan kehendak seluruh warga tanpa kecuali. Dengan suasana mayoritas tadi setiap individu wajib taat dan dengan suara mayoritas, setiap individu berhak atas pemilikan dan hak-hak lainnya. Kedua, pactum subjektionis, maka mayoritas warga menyerahkan

\footnotetext{
${ }^{16}$ Friedman, ibid, h.43.
} 
kekuasaannya kepada pemerintahan yang berfungsi untuk melindungi individu. Sepanjang tidak melanggar janjinya, pemerintah tidak akan dicabut kekuasaannya.

Rasseau mmenciptakan volonte generale di satu pihak dan mengakui kemerdekaan serta persamaan hak-hak manusia, keduanya tidak dapat diambil alih. Ia juga menggunakan konstruksi perjanjian masyarakat, namun bukan sebagai fakta sejarah melainkan hypothetical construction of reason belaka. Deduksinya mengenai kebebasan alami dan persamaan hak-hak kemanusiaan di dasarkan kepada kepentingan yang terpusat pada komunitas primitif yang di dalamnya manusia hidup serasi, puas dalam hubungannya dengan masyarakat, melalui kerja keras untuk mencukupi kebutuhan dan memudahkan kehidupannya. Berbeda dengan Hobbes dan Locke yang mendasarkan pada egoisme individu (mementingkan diri sendiri). Bagi Rasseau, perjanjian masyarakat diadakan untuk melindungi masyarakat, karena kesulitan memperoleh superioritas bagi komunitas organis maupun hak-hak alami manusia. Argumen mengenai kebebasan dan kesamaan kedudukan manusia adalah dasar bagi kebahagiaan mereka. Awalnya berada dalam kehidupan komunitas primitif, kemudian hilang ditenah-tengah peradaban modern.

Sekarang perlu ditemukan bentuk organisasi sosial yang menjamin hakhak alamiah menganai kebebasan dan persamaan. Pada perjanjian masyarakat, manusia bersatu untuk menjamin kebebasan dan persamaan individu (manusia) dalam suatu negara. Eksistensi dan justifikasi negara hanya bersumber dari jaminan terhadap kebebasan dan persamaan. Setelah memperoleh hak-hak itu, maka hak-hak tadi tidak lagi menjadi hak alamiah, karena telah berubah menjadi hak sipil bagi semuanya. Negara dan hukum negara tetap menjadi subjek kehendak umum yang mendukung menciptakan negara melakukan perlindungan yang lebih baik bagi kebebasan dan persamaan. Implikasi kehendak umum tidak dikembangkan lebih lanjut oleh Rasseau untuk menjadikan semua kesimpulannya konsisten. Namun ia memuji kedaulatan rakyat yang langsug disbanding dengan demokrasi perwakilan melalui parlemen.m Rupanya Rasseau tidak mampu melepaskan pikirannya dengan lingkungan kehidupannya di Swiss, suatu kota kecil pada masanya. ${ }^{17}$

Pembahasan singkat di atas menunjukkan bahwa dari seluruh konstruksi perjanjian masyarakat yang diajukan telah menghasilkan kesimpulan yang berbeda-beda. Ada yang menganggap bahwa perjanjian mayarakat itu demikian benar-benar ada dalam sejarah. Namun ada pula yang mengatakan sebaliknya. John Locke berpendapat bahwa di samping mengadakan pactum unionis masih

\footnotetext{
${ }^{17}$ Dalam Friedman, ibid.
} 
diakui oleh pactum subjectionis, Hobbes mengatakan bahwa semata-mata pactum subjectionis, sementara Rasseau mengatakan semata-mata pactum unionis.

Kekuasaan dalam negara diselenggarakan oleh suatu organisasi teknis yang disebut pemerintah. Organisasi ini dapat dibedakan bentuknya berdasarkan tata cara pengangkatan kepala negaranya. Jika jabatan kepala negara diwariskan kepada keturunannya atau kepada anggota keluarga lainnya, maka pemerintahan negara itu disebut monarhi (kerajaan). Masih saja dapat dibedakan menjadi monarschi absolut, monarshi konstitusional dan yang parlementer. Sebaliknya jika jabatan kepala negara didasarkan atas pilihan rakyat (langsung atau tidak langsung) maka negara itu berbentuk republik. Republik ini dapat pula dibedakan menjadi republik absolut, konstusional dan yang parlementer, untuk pembahasan lebih lanjut maka dibedakan bentuk negara, menjadi: negara kesatuan yang didesentralisasikan dan gabungan dari negara-negara. Bentuk negara terakhir dirinci menjadi protektorat, koloni, konfederasi, commonwealth of nation dan uni (real atau personel. $)^{18}$

Kekuasaan tertingi (unsur pertama untuk disebut negara) dijalankan dalam suatu wilayah (unsur kedua). Wilayah itulah yang menjadi lingkungan kerja kekuasaan tertinggi negara dan menjadi tempat menyelenggarakan kekuasaan secara efektif. Wilayah kekuasaan negara tidak hanya meliputi dataran, melainkan juga disekitarnya, kesemuanya dalam batas-batas tertentu. Perkembangan selanjutnya wilayah negara meliputi udara, namun wilayah yang disebut terakhir belum menimbulkan persoalan hukum tatanegara pada masa kerajaan nusantara dan belum dibatasi oleh pemerintah Hindia Belanda. Bahkan wilayah darat dan laut kerajaan nusantara belum memiliki batas-batas yang jelas dan tegas, ${ }^{19}$ tetapi dikecualikan pada kerajaan-kerajaan di Sulawesi Selatan, ${ }^{20}$ mengakui pula bahwa hukum adat mengenai batas-batas wilayah laut territorial di kepulauan Maluku.

Unsur ketiga dari negara adalah warganegara. Hukum tatanegara menunjuk warganegara sesuai aturan tertulis, yaitu undang-undang kewarganegaraan. Ketentuan tertulis itu tidak dikenal dalam hukum tatanegara adat, tidak pula memiliki kodifikasi. Namun demikian tidak berarti bahwa negaranegara nusantara tidak mempunyai rakyat, penduduk yang merupakan warga negaranya. Terhadap warga negara yang terdapat pada kerajaan nusantara yang beraneka ragam bentuknya itu, dinilai oleh Van Vollen Hoven tidak mempunyai

\footnotetext{
${ }^{18}$ Utrecht dan MS Djindang, Loc cit, h.339-345

${ }^{19}$ Di Belanda sendiri baru ditetapkan wilayah udaranya pada tahun 1914. Lihat Van Vollen Hoven. Loc cit, h. 23
}

${ }^{20}$ V.E. Kron, Problemen der Makassar-Buginesche semenleving, DKI CVIII, 1952 h.57. 
kewarganegaraan asing. Akan tetapi di Makassar (umunya di Sulawesi Selatan) menurut Resink justru menarik batas antara warga negara yang berstatus orang asing dengan status warganya negaranya sendiri. Di Bali dan Lombok juga demikian. Warga kerajaan (kawula) dan yang bukan (orang asing) dapat ditelusuri perbedaannya dari jumlah paswara dan perjanjian. Tidak ada ketentuan tertulis yang mengatur unsur-unsur kekawulaan dan kedudukan seseorang sebagai orang asing.

Perlu dicatat bahwa baik kawula kerajaan maupun orang asing yang pindah atau melakukan perjalanan, memerlukan izn penguasa setempat. Fungsi pengawasan terhadap orang asing terpusat pada subandar. Oleh karena itu pengawasan ketat dilakukan untuk menghindari dan mengetahui adanya pelarian dari satu kerajaan. Berhubung seringnya terjadi peperangan, maka dalam rangka mencegah pelarian kawula kerajaan, raja-raja Bali membuat perjanjian dengan memasukkan klausula penyerahan, karena sering pula warga kerajaan kehilangan kekawulaannya. Kondisi ini menyebabkan dikenalnya lembaga hukum suaka. Kesemua itu dapat dikatakan bahwa hukum tatanegara adat telah mengenalnya.

\section{Perjanjian Masyarakat Sebagai Fakta dan Struktur Organisasi Pemerintahan (Studi di Kerajaan Bone)}

Dari pembahasan teori di atas, maka yang berpendirian bahwa perjanjian masyarakat, pastilah dikaitkan dengan asal mula kerajaan kerajaan besar di Sulawesi Selatan. Untuk dapat menganalisis teori itu, tentu akan dipertemukan dalam peristiwa sejarah To Manurung. ${ }^{21}$ Namun karena setiap kerajaan selalu diawali dengan peristiwa to manurung, maka pembahasan mengenai hal ini hanya dikhususnya kepada kerajaan-kerajaan besar.

Di Sulawesi Selatan terdapat tiga kerajaan besar yang berdasarkan informasi sejarah mampu mempengaruhi kerajaan-kerajaan kecil dan menaklukkannya. Dengan demikian kekuasaan sangat kuat, luas dan mencapai tingkat kemakmuran rakyat di kala itu. Salah satunya akan diuraikan di sini adalah Kerajaan Bone.

Diperkirakan Kerajaan Bone berdiri dan bertahan selama kurang lebih 6 abad, yaitu dari abad ke 15 samai abad ke 20. Jadi lebih dahulu berdiri dari Kerajaan Gowa. Sebelum berdirinya Kerajaan Bone, telah berdiri kerajaankerjaan kecil seperti, Babuae, Mampu, Pattiro, Awampone, Cina dan Palakka.

21 Tokoh To Manurung sebagai pendiri kerajaan, kemudian berkembang menjadi mitos kekuasaan yang bersifat genetic - menjelma kemudian menjadi elit aristocrat yang diberi legalisasi oleh rakyat sebagai pemegang kekuasaan. Awalnya kekuasaan itu bersifat turun temurun, kemudian mengalami berbagai perubahan sehingga kekuasaan monarschi berubah menjadi monarschi konstitusional dan cenderung demokratis. 
Masing-masing berdiri tanpa ikatan ketatanegaraan . Mereka sering terlinat dalam sengketa tanah perbatasasn atau hal lain menimbulkan peperangan.

Dalam suasana yang demikian itu, atu sama lain sering saling menghancurkan, sehingga terjadi kekacauan yang berlangsung cukup lama. Muncullah To Manurung di Matajang. Di tempat itu telah berhuni masyarakat yang telah mengenal kaum-kaum atau kelompok-kelompok masyarakat. Mereka menghuni areal pertanian yang cukup luas untuk dikelolah memenuhi kebutuhan ekonominya, mereka itulah yang disebut anang. Mereka mendiami negeri-negeri kecil yang disebut wanua yang dipimpin oleh seorang matoa. Ketika aitu ada 7 (tujuh) wanua mendukung To Manurung menjadi penguasa (raja). Kemudian To Manurung diberi egelar mata silompoe. Ketujuh wanua (komunitas masyarakat kecil) yang dimaksud adalah:

1. macege;

2. Ponceng;

3. Tibojong;

4. Tanete Riattang;

5. tanete Riawang;

6. Ta'; dan

7. Ujung

Ketujuh Wanua itu mempersatukan diri dalam satu ikatan wanua yang disebut kawerang. Inilah yang kemudian menjelma menjadi Watampone sebagai pusat kerajaan Bone tempat bertahta Mangkau Bone Pertama Mata Silompoe. Sebelum berdirinya Kerajaan Bone antara calon Mangkau Bone Pertama dengan ke tujuh Matoa Wanua melakukan perjanjian kesepakatan. Bunyi perjanjiannya adalah sebagai berikut:

- $\quad$ Rakyat: anginlah engkau dan kami daun kayu, kemana engkau berhembus kesana kami ikut serta, kehendakmu menjadi kehendak kami pula; apa nian titahmu kami junjung; perintahkanlah, kami laksanakan; mintalah dari kami, akan kami berika; Engkau menyeru, kami akan datang; terhadap anak isteri yang engkau cela, kami pun mencelahnya, akan tetapi pimpinlah kami ke arah ketenteraman, kesejahteraan dan perdamaian;

To Manurung: Ke atas batok kepala janjimu wahai orang kami tempatkan dalam rumah keemasan; kemuliaan janjimu ketika ini engkau bersatu padu, menerima kami sebagai rajamu.

Tampaklah bahwa sesungguhnya Kerajaan Bone berdiri berdasarkan. perjanjian yang memerintah (pangreh) dengan yang diperintah (direh). 
Dasarnya bertumpu pada keinginan bersama dari rakyat. Segala janji yang diucapkan rakyat, maka To Manurung menempatkannya ke dalam suatu cita-cita yang luhur, suatu janji pemenuhan secara tidak langsung kepada rakyat yang telah menobatkannya menjadi raja (mangkau Bone). Berjanji pula untuk memenuhi kemauan rakyat (hakhak rakyat) sekaligus hak-hak yang melekat pada raja.

Di bawah pemerintahan Mata Silompoe, kehidupan rakyat semakin membaik, mengakibatkan banyak kerajaan di sekitarnya bergabung dan atau ditaklukkan. Dalam menjalankan pemerintahan, ke tujuh Matoa Wanua yang mengangkatnya dijadikannya menjadi kabinet, selanjutnya disebut Arung Pitu. Bersama mereka inilah Bone kemudian menjadi kerajaan yang mempunyai kedudukan cukup disegani oleh kerajaan-kerajaan lainnya.

Terdapat tiga kebijakan yang diletakkan oleh Mangkau Bone, yaitu pertama, menentukan hak milik. Kedua, menanamkan dasar-dasar hukum sebagai pedoman ketentuan masyarakat. Ketiga, membuat selembar janji sebagai lambing Arung Mangkau, apabila bergian ke wilayah-wilayah hukum kekuasaannya yang disebut worongporong.

Sistem pemerintahan kerajaan Bone, semakin hari semakin memperlihatkan perbaikan. Pada masa pemerintahan Mangkau Bone ke tiga La Saliyu Korampelua, mengangkat dua orang pembantu masing-masing To Suwalle dengan tugas mendampingi Mangkau Bone meladeni segala urusan pemerintahan ke dalam atau Pemerintahan Dalam Negeri termasuk urusan istana dan To Salawakka yang bertugas mewakili Mangkau Bone mengurus segala hal berkaitan dengan tugas luar atau Pemerintahan Urusan Luar Negeri, termasuk urusan dengan kerajaan-kerajaan lain.

Kedua jabatan itulah sehingga muncul nama-nama jabatan baru antara lain To Marilaleng dan makkadenge tana. Di samping ke dua jabatan itu dibuat pula dua pani masing-masing Panji yang disebut Cella ri atau dan Cella ri Abeo (bate). Kemudian masing-masing Panji ditentukan seorang pemimpin yang susunannya sebagai berikut :

\section{Bate Worongporongnge}

Dipergunakan dan diikuti oleh rakyat (masyarakat) majang, Maroanging, Bukaka, Kawerang, Pallengoreng, mallari, pimpinannya ditetapkan Matoa Majang.

\section{Bate Cella ri Atau}

Dipergunakan oleh masyarakat Lemoape, Masasalle, Macege, Belawa, pimpinannya ditetapkan To Suwalle dengan Gelar kajao Ciung.

\section{Bate Cella ri Abeo}


Dipergunakan oleh masyarakat (rakyat) Araseng, Katumpi, Ujung Padangcengnga, Madello, pimpinannya ditetapkan To Salawakka dengan gelar Kajao Araseng.

Pada maa pemerintahan Raja Bone ke enam, Mangkau La Tenri Rawe yang terkenal memiliki sifat-sifat kejujuran, baik hati dan pemurah. Beliau menambah aparat kerajaan seperti To Makajannang (pasukan Bangsawan) dan kelompok panre (Terampil/tukang). Ketika itu didampingi oleh seorang filsuf hukum bernama Kajao Laliddong yang terkenal selain sebagai diplomat ulung, juga sebagai konseptor dalam berbagai hal yang berkitan dengan penyelenggaraan pemerintahan Kerajaan Bone. Antara lain menetapkan persekutuan hukum sendisendi kepastian hukum, berbunyi sebagai berikut:

Tak akan saya ambil sesuatu batang kayu yang tersandar, yang bukan saya menyandarkannya, tak akan saya mengambil se batang kayu yang sudah ditetak kedua ujungnya yang bukan saya menetaknya, tak akan saya mengambil tanaman yang bukan saya menanamnya.n apabila saya mengambil tanaman yang bukan saya menanamnya, maka akan keluar masuklah musuh di tanah Bone.

\section{PENUTUP}

Menurut pengamatan penulis, kerajaan daerah Bugis lahir sebagai suatu Negara didasarkan pada perjanjian masyarakat, yakni antara to manurung dengan rakyat. Sebagai organisasi yang disebut Negara, di dalamnya diakui adanya suatu sistem pengatur yang disebut hukum (pangadereng).

Era sistem ketatanegaraan adat berlaku, organisasi yang berbentuk kerajaan melaksanakan berbagai fungsi-fungsi yang mirip sama dengan fungsi Negara modern. Hal itu dapat dilihat dari berbagai urusan dalam dan luar kerjaan telah diatur dengan rapi meskipun sederhana.

Pada aspek penegakan hukum, umumnya orang-orang Bugis sangat mencintai kebenaran dan keadilan, bahkan aspek kepastian hukum telah dihidupkan. Dalam kehidupan bermayarakat menjunjung tinggi nilai intergritas antara lain, orang Bugis tidak gentar melaporkan penguasa adat yang bertindak sewenang-wenang atau ceroboh kepada rakyat. Mereka bersifat terbuka, tidak suka menyembunyikan persoalan. Senantiasa bergembira, setia dan memiliki semangat dan gairah yang tinggi dalam berusaha (bidang pertanian). Semua itulah yang menjadikan mereka menjadi simpatik.

Aspek Kewiraan Bugis sangat diperhatikan (tidak hanya dalam ranka menghadapi peperangan, tetapi juga dalam, perantauan). Menegur dan memperingati pemerintah yang tidak menjalankan secara prosedural pemerintahan sesuai dengan hukum perjanjian dengan rakyat. 


\section{DAFTAR PUSTAKA}

Andi Zainal Abidin Farid, Persepsi Orang Bugis Makassar Tentang Hukum, Negara dan Dunia Luar, Alumni, Bandung, 1983.

, Pandangan Orang Sulawesi Selatan Menurut Lontarak yang Dapat Dijadikan Penggerak Pembangunan Daerah, (Makalah) 1986.

Wajo Pada Abad XV-XVI (Suatu Penggalian Sejarah Terpendam Sulawesi Selatan dari Lontarak), Alumni, Bandung, 1985.

Friedman, Legal Theori, Steven and Sons Ltd. 1953.

Indra Chanra, Kerajaan Bugis Bone Dalam Konteks Kerajaan Tellumpoccoe, (Makalah), 1986.

Koentjaraninrat, Manusia dan kebudayaan Indonesia, Djambatan, Jakarta, 1976.

Mattulada, Lontarak La Toa (Sumber Informasi Tentang Kebudayaan Di Sulawesi Selatan), Makalah, 1986.

Mohamammad Koeno, Hukum Mengenai Tata Susunan Masyarakat Dalam Hukum Adat, 1972. Utrecht - M. Saleh Djindang, Pengantar Dalam Hukum Indonesia, Jakarta, Sinar Harapan Balai Buku Ikhtiar, 1983.

Mustaming Dg. Matutu (Dosen Fakultas Hukum Unhas) Selayang Pandang (tentang) Perkembangan Tipe-tipe Negara-Negara Modern, Pidato Lustrum IV, Fakultas Hukum Unhas, Ujung Pandang, 1972.

Logeman, Over de Theorie Van een Steling Staatrecht. NV. Mahabarata, Amsterdam, 1947.

Shelly Errington, Sirik, Darah dan Kekuasaan Politik Kerajaan Luwuk Zaman Dahulu, Bingkisan Budaya Sulawesi Selatan, Th.. I Nomor 2 Yayasan Kebudayaan Sulawesi Selatan, 1977.

Ter Haar, Azas-Azas Hukum Adat ( Terjemahan dari judul : Beginselen en Stelsel Van Het Adat Recht ) Djambatan, Jakarta, 1939.

V.E. Kron, Problemen der Makassar-Buginesche semenleving, DKI CVIII, 1952. 